\title{
Power relation of the 212 Islamic Group and the government in the 2019 presidential election
}

\author{
Relasi kekuasaan Kelompok Islam 212 dan pemerintah di pilpres 2019 \\ Moch. Mubarok Muharam ${ }^{1}$, Kacung Marijan ${ }^{2 *}$ \& Airlangga Pribadi Kusman ${ }^{2}$ \\ ${ }^{1}$ Government Science Study Program, Faculty of Social and Political Sciences, \\ Universitas Darul 'Ulum Jombang \\ ${ }^{2}$ Department of Political Science, Faculty of Social and Political Sciences, \\ Universitas Airlangga \\ Address: ${ }^{1}$ Jalan Gus Dur 29 A, Jombang, East Java 61419 \\ ${ }^{2}$ Jalan Dharmawangsa Dalam, Airlangga, Surabaya, East Java 60286 \\ E-mail: kacung.marijan@fisip.unair.ac.id
}

Article History: Received 22 July 2020; Accepted 24 June 2021; Published Online 10 July 2021

\begin{abstract}
The 212 Islamic Group was in opposition with the government of Joko Widodo (Jokowi) in the 2019 presidential election. This group made militant resistance against Jokowi in the presidential election. This resistance influenced the presidential election contestation became more dynamic and fierce. The fierce contestation had divided the community into two camps, namely the pros and cons of Jokowi. This study explored and analyzed the resistance of the 212 Islamic Group against the government in the 2019 presidential election. This study was a qualitative study, interviewing 12 informants, consisting of the 212 Islamic Groups, Moderate Islamic Groups, Indonesian Ulema Council, online media, and academics. This study showed that The 212 Islamic Group can offset the government's political influence so that the presidential election becomes more dynamic and balanced. However, the resistance of this group can be substantial (prominent) because of the narration about the rise of Islam and their ability to ideologize mosques and social media. This paper concluded that there was a resistance of the 212 Islamic Group to the country because Jokowi was considered secular and detrimental to Islam in politics and law, such as disbanding Hizbut Tahrir Indonesia (HTI).
\end{abstract}

Keywords: 212 Islamic Group; government; Islamism; the 2019 presidential election

\begin{abstract}
Abstrak
Kelompok Islam 212 beroposisi dengan pemerintah Joko Widodo (Jokowi) dalam pemilihan presiden 2019. Kelompok tersebut melakukan perlawanan militan terhadap Jokowi dalam pemilihan presiden. Perlawanan ini memengaruhi kontestasi pemilihan presiden menjadi lebih dinamis dan sengit. Pertarungan sengit itu telah memecah masyarakat menjadi dua kubu, yakni pro dan kontra terhadap Jokowi. Penelitian ini mengkaji dan menganalisis perlawanan Kelompok Islam 212 terhadap pemerintah pada Pilpres 2019. Studi ini merupakan penelitian kualitatif dengan mewawancarai 12 informan yang terdiri dari Kelompok Islam 212, Kelompok Islam Moderat, Majelis Ulama Indonesia, media online, dan akademisi. Studi ini menunjukkan bahwa Kelompok Islam 212 dapat mengimbangi pengaruh politik pemerintah sehingga pemilihan presiden menjadi lebih dinamis dan seimbang. Namun, perlawanan kelompok ini bisa menjadi substansial (menonjol) karena narasi tentang kebangkitan Islam dan kemampuan mereka untuk mengideologikan masjid dan media sosial. Tulisan ini menyimpulkan adanya perlawanan Kelompok Islam 212 terhadap negara karena Jokowi dianggap sekuler dan merugikan Islam di bidang politik dan hukum, seperti membubarkan Hizbut Tahrir Indonesia (HTI).
\end{abstract}

Kata kunci: Kelompok Islam 212; pemerintah; Islamisme; pemilihan presiden 2019

\section{Introduction}

This paper aimed to discuss the opposing power relations between the 212 Islamic Group and the Indonesian government led by President Joko Widodo, hereafter called Jokowi, in the 2019 presidential election. The group's opposition is interesting to discuss because it was carried out with heroism and 
militancy. Furthermore, the group also used Islamic symbols and identities, and the opposition in its development had divided the community to those who were pro and contra against Jokowi, those considered devout to Islam or accused of ignoring Islamic teachings.

There have been several studies conducted by academics discussing the relationship between Islam and the government. In understanding this relationship, Hefner (1993) and Heiduk (2012) saw that Islam can establish harmonious and synergic power relations with the government. On the contrary, Van Bruneissen (2002), Barton (2010), and Fealy \& Bush (2014) stated that the relationship between Islam and the government is always tinged with conflict. This research tried to fill the gap between these two points of view, and contradicted the arguments of Hefner (1993) and Heiduk (2012); while supporting the arguments of Van Bruneissen (2002), Barton (2010), and Fealy \& Bush (2014). While they stated that the conflict occurs in an authoritarian government, this research argued that the conflict between Islamism (the 212 Islamic Group) and the government could occur in a democratic era.

The 212 Islamic Group held a demonstration of Defending Islam Action 3 (Aksi Bela Islam 3, hereafter called ABI 3) in 2016. The goal of ABI 3 was to get Basuki Tjahaja Purnama, hereafter called Ahok, the Governor of Jakarta, to be jailed (Miichi 2019). The action spearheaded by the MUI Fatwa Guard National Movement (GNPF MUI) - a name used by 212 Islamic Group - not only made Ahok be jailed but also made him who was incumbent in the 2017 Jakarta Governor Election, failing to maintain his position as the number one in the capital city (Hadiz 2018).

There are two points of view about ABI3 conducted by the 212 Islamic Group. Fealy (2016) stated that the action was not an Islamic movement, while Hadiz (2018) and Mietzner (2018) stated otherwise. However, in this research, this action was considered as an Islamic movement. While Hadiz (2018) stated that the cause of the presence of ABI 3 was the existence of an oligarchic system and Mietzner (2018) stated that an open and democratic political system allowed ABI 3 to emerge, this research saw the causal factor of this action was the discourse on the government led by Jokowi as secular. Along with this factor, another factor that had driven this action to rise since 2016 till today and could be accepted widely in Indonesia was because of the ideological nation of public space, the creation of political momentum, and a change in the group's approach from a street group to institutionally oriented one.

Although ABI 3, known as the 212 action, aimed to prosecute Ahok, the action was also carried out to express the disappointment of Islamist members who are members of the 212 Islamic Group against Jokowi's government (Mietzner 2018). The group felt disappointed and angry with Jokowi because the Solo's former mayor was considered secular and not profitable for Islam (Natsir 2017). Jokowi was considered secular because of several aspects. First, the actions and policies carried out by Jokowi in the field of security, society, and religion were considered unfair and detrimental to Islam. In the field of security, the policies made by the government through the act of Minister for Political, Legal, and Security Affairs, Luhut Binsar Panjaitan, were considered unfair (Prasetyo 2019). Second, in dealing with Islamic terrorism, the government acted harsher and without compromise against the separatist movement carried out by the Wenda Brothers in Papua. Third, in the social and religious fields, the group was disappointed by draft Bills' emergence on the Elimination of Sexual Violence (PKS) in early 2016. The Bill was considered strengthening the practice of adultery, LBT, abortion, and sexual violence. During the 2012 Jakarta Government Election and the 2014 Presidential Election, Jokowi was nominated by a secular political party, which was PDIP. Fourth, Jokowi was considered pro-capitalism because he made foreigners control the economy, where capitalism is considered synonymous with secularism. Fifth, Jokowi was always considered to support Ahok's policies and actions as the Governor of Jakarta; Ahok himself is considered an official at odds with Islam because immoral acts such as gambling, alcohol consumption, and prostitution increased during his leadership, and he is non-Muslim. The involvement of Muslims in the movement that wanted Ahok to be imprisoned was due to the alleged blasphemy of religion, in addition to being identified as a party or group that made Jakarta's citizens experience poverty (Huda 2019). 
This research assumed that in the relationship between the 212 Islamic Group and the government, the government was an entity that has no power to dominate. On the other hand, the 212 Islamic Group became a more hegemonic group in its relations with the government. Therefore, public reasoning favors the actions and perceptions raised by the group. The research is necessary because first, the influence of the 212 Islamic Group cannot be neglected, and it is supported by the fact that the influence was strengthened after ABI 3. Second, the fact shows that intolerant Islamism activities had increased since the reformation era compared to the New Order Era. According to Van Dijk \& Kaptein (2016), after Soeharto ruled the government, the practice of intolerance has doubled from before. Between 1967 and 1998 (the era of the New Order government), intolerance was recorded 470 times, while from 1998 to 2010, the practice of intolerance was carried out 700 times. Meanwhile, a report from the Wahid Institute stated that there were 274 attacks on religious minorities (Van Dijk \& Kaptein 2016). The Wahid Institute is a Non-Government Organization (NGO) that wants to fight for religious plurality and tolerance in Indonesia, led by Yenny Wahid, daughter of Abdurrahman Wahid, the fourth President of Indonesia and a well-known defender of minority rights in Indonesia. In addition, since the reformation, many sharia regulations have appeared in several cities. Third, the struggle of civil society against the Islamism movement in the reformation era has decreased compared to the New Order Era. One reason is that many civil society activists choose to join political parties rather than remain social workers. This situation makes it easier for Islamist activists to spread their teachings and carry out religious movements. Fourth, the Reformation Era has made it easier for all parties, including Islamist groups, to express their freedom of speech, association, and social actions. The public space that is opened as wide as possible is imagined to create an egalitarian discussion space that becomes a quickly filled space with Islamic teachings and terms.

This research is interesting because it looked at the cause of the strengthening of the Islamism movement by the 212 Islamic Group. This research is different from previous research, such as those conducted by Hadiz (2018) and Mietzner (2018). It can be an input for the government to respond and take reasonable action against the existence of the Islamism movement. Furthermore, this research can serve as a reference for other researchers to research the Islamism movement in the future. Finally, it is hoped that this research will create new awareness from civil society groups and all elements of the nation to be active in promoting a more tolerant lifestyle.

\section{Research Method}

This paper was based on qualitative research by analyzing the theory of power by Michael Foucault. In collecting primary data from informants, the researcher conducted in-depth interviews with twelve resource persons, including nine people from 212 Islamic LUB (FPI), NAT (MIUMI), RAS (Wahdah Islamiyah), KHA(FUI), MAR (GNPF Ulama), HAS (GNPFMUI), MAA(PA 212), HER (Media Forum Activist), GUN (Forum Jurnalis Muslim), two people from Moderate Islamic Groups, namely SIR and $\mathrm{ABD}$, and one person from the online media leader, namely NIA. Interviews were conducted from March to August 2019. The in-depth interviews obtained information about the power relations between the 212 Islamic Group with the government (Jokowi), especially in the 2019 presidential election. In addition, this study also obtained secondary data from books and journals to strengthen the data obtained from interviews.

In this qualitative research, the interview is considered an interaction whose formation is assisted by the researcher and the subject. In the analysis, the interviewer and the subject are considered equal. In-depth interviews were conducted with several (elite) figures of the 212 Islamic Group. Structured interviews were conducted by using the same questions on each subject. Interviews were conducted repeatedly, and each interview was conducted by repeating the questions raised by the previous ones. It aimed to reconfirm the questions previously raised to figures from the '212 Islamic Group'. The other stakeholders' opinion relevant to the problem under study is also included to strengthen the quality of the research. Data collection is complete when the data has experienced a saturation point. It means that the data collected is believed to be sufficient to answer the questions posed. This analysis technique 
is carried out by using categories for the data obtained, and then the next step is to display the data. Moreover, it is interpreted by using the theory of power from Michael Foucault.

\section{Results and Discussion}

After the Defending Islam Action did by the 212 Islamic Group and the 2017 Jakarta Government Election relations, the relationship of the group and the government did not improve and even tended to be hostile. The enmity led the 212 Islamic Group to fight Jokowi in the 2019 Presidential Election. After the 212 Jakarta Acts and government election in Jakarta, the dislike of the 212 Islamic Group or the Ulama Fatwa Guard National Movement (GNPF), a substitute name for the GNPF MUI-against Jokowi is getting stronger. This dislike is due to several factors. First, Jokowi's government emphasizes the importance of separating politics and religion in 2017. Second, there was the liquidation of the Indonesian Hizbut Tahrir Indonesia (HTI) by the government. Third, there is a suspicion of the criminalization of the Islamic ulama. The ulama's criminalization occurs when the cleric is arrested without going through legal processes following the rules. Alleged criminalization was carried out on the GNPF Ulama or 212 Islamic Group figures, including Rizieq Shihab, Bachtiar Natsir, and Al-Khaththath. Fourth, Jokowi's policy is considered pro-market, raising the cost of basic electricity, fuel, fertilizer prices and carrying out infrastructure and toll road construction.

The 212 Islamic Group figure and the Chairperson of the Islamic Defenders Front (FPI), LUB, stated:

"The people do not enjoy toll road construction because they cannot use it due to the expensive tariff. So, this development only benefits foreign parties. The development will be funded by external, including other developments so that the profits will be external. So, who will benefit from the toll road construction?"

The Jokowi's Government, aside from being considered to have benefited foreigners, also assumed to dominate the Indonesian economy, including facilitating foreign products to dominate the domestic market. The group expressed its concern with the emergence of the Ministry of Trade Regulation Number 64 of 1974. The regulation made imported products in the textile industry and textile products (TPT) from China freely enter Indonesia. The entry of products from China made the textile industry within the country suffer a setback, resulting in extraordinary termination of labor. Chairperson of the GNPF Ulama, MAR, said:

"Many government's policies and actions are secular, and that should not be allowed to continue. Therefore, we are determined to beat Jokowi in the 2019 presidential election. To make the desire to defeat Jokowi can be achieved, we hold an Ijtima Ulama (Ulama Agreement) event. The event was aimed at getting input from scholars and Islamic leaders on the presidential election issues. The 212 Islamic Group can obtain that support from the ulama. They are a political network from the GNPF Ulama who come from all over Indonesia."

In addition to secular policies and actions, Jokowi's closeness to certain political parties makes him disliked by the 212 Islamic group. In this case, the Chairman of the Nadlatul Ulama Executive Board, SIR, said:

"Jokowi's closeness with PDIP made the 212 Islamic Group detest him. Besides being nominated by secular political parties, Jokowi's good relations with the Moderate Islamic Group have made him disliked by Islamism."

The group continues to emphasize that the Ijtima Ulama event is an effort to listen to the ulama's aspirations and, at the same time, respect the ulama. MAR stated:

"We involved the ulama in discussing the presidential election problem because we wanted to glorify the ulama. We want scholars to continue to be involved in making essential decisions in political and governmental matters." 
Even so, what is said by MAR is not the primary desire because, in fact, the main goal to gather scholars from all over Indonesia is to give legitimacy to the desire to fight and defeat Jokowi in the presidential election. In Foucault's perspective, MAR's statement could be understood as an attempt to conceal his genuine desire, which is getting an endorsement from the ulama towards his political decisions.

KHA, the leader of the 212 Islamic Group, who is also the secretary-general of the Muslim Community Forum of 212 Islamic Group, stated:

"The support of the ulama gave us many votes in the presidential election because the ulama had many followers. In addition, with the ulama behind us, it will make Muslims support us. If there is a group there, are there any scholars who support it?"

The political legitimacy obtained from the ulama will make it easier for them to gain political influence. Because the Ijtima Ulama program is an attempt to gain legitimacy towards all decisions made by the GNPF Ulama or 212 Islamic Group, it is not surprising that the decisions at the event mainly directed by groups that made Rizieq Shihab the icon of the movement. In this case, the critical decision produced was integrity, involving 17 criteria that must be fulfilled and implemented by the president or vice president supported by the forum. The 17 criteria include 1) practicing religious and ethical values; 2) preventing people from following understandings that will destroy existing norms; 3 ) making policies that consider the principles of representation, justice, and proportionality; 4) preventing the blasphemy of religion; 5) strengthening Islamic brotherhood; 6) protecting Islamic wealth in order to create the prosperity of the people; 7) safeguarding the Republic of Indonesia from the threat of separatism; 8) imperialism and communism; 9) allocating adequate funds for general education and religion; 10) supporting the struggle for Palestinian independence following the spirit and mandate of the 1945 Constitution; 11) repatriating Shihab to Indonesia and not criminalizing ulama.

These seventeen criteria are ideas that were raised more by the GNPF Ulama (the 212 Islamic Group) rather than those by scholars appointed from the regions and were adopted from the wishes of Rizieq Shihab. Even though Shihab was in Saudi Arabia at that time, because all the drafts that were used as integrity pacts were discussed and received directions from him, it made Shihab able to control these activities from abroad (interview with LUB on 26 March 2019 in Bogor). Because these criteria are more considered by the GNPF Ulama or Shihab, the integrity pact was created as a value believed to be the antithesis of Jokowi. Seventeen criteria in the integrity pact are codes or symbols that the 212 Islamic Group does not support Jokowi in the presidential election in 2019. Therefore, after making the integrity pact, Ijtima Ulama 1 gave support to figures considered appropriate to compensate or defeat Jokowi in the presidential election.

For this reason, at Ijtima Ulama 1, the Islamic scholars, and leaders who participated decided to elect Prabowo Subianto as a presidential candidate. In addition, the ulama and Islamic leaders also chose Abdul Somad Batubara, a cleric with a dai background, and Salim Al Jufri, an ulama with a political party manager background, as a vice-presidential candidate. Because Prabowo Subianto did not want the two vice-presidential candidates, then later in Ijtima Ulama 2, the GNPF Ulama (212 Islamic Group) had a dialogue with the ulama and Islamic leaders. As a result, they decided to support Sandiaga Uno as a candidate for the vice president to accompany Prabowo Subianto. Support for Sandiaga Uno turned out to be the right decision because he could win the voters' sympathy and support. KHA stated:

"In his later journey, we believe that Sandi is the right companion for Prabowo. With his financial strength and high mobility, Sandi's figure will increase electability. Especially seeing the acceptance of women towards him makes me believe that the Prabowo-Sandi pair can win the presidential election and bring Indonesia to be better." 
MAR said:

"The 212 Islamic Group believes that the support of the ulama towards Prabowo has become energy for them to struggle totally in the presidential election, and at the same time, this support has made Jokowi's party fearful."

Because of these fears, Jokowi then chose Maruf Amin, Chair of the Indonesian Ulama Council (Majelis Ulama Indonesia, MUI), and Rais Syuriah, Executive Board of Nahdlatul Ulama, the vice-presidential candidate. Amin, as Chairman of the MUI, has issued a religious view stating Ahok committed religious defamation. This religious view becomes a legitimate tool for the 212 Islamic Group to carry out Islamic Action or Action 212 in 2016.

Amin's appointment as his assistant in the presidential election meant that Jokowi did not want to lose the voice of the Islamic ummah. Jokowi did not want the voice of Muslims to unite to support Prabowo. For Jokowi's party, the support of Islamic scholars and leaders in the Ijtima Ulama program can strengthen the image that Prabowo represents the overall voice of Islamic scholars. In addition to giving concern to Jokowi, the cleric's support to Prabowo has strengthened the belief in the 212 Islamic Group that changes in national leadership cannot be prevented. In this context, the Chairperson of the 212 Alumni Brotherhood, MAA, stated: "The support of the ulama and the Muslims have given us the confidence that change cannot be stopped. The voice of Muslims cannot be prevented; the revival and unity of Islam have come."

In addition, the support and arduous struggle of Islamic women's groups strengthened the struggle of 212 Islamic Group 21 in the presidential election. MAA stated that "The presidential election is important, as part of uniting Muslims to realize the revival of Islam."

In that case, the 212 Islamic Group considers defeating Jokowi in the presidential election to make Islam not a periphery in political and economic life. Chair of the Indonesian Ulama Council Fatwa Guard National Movement, NAT, stated that "The marginalized Islamic condition was not following its position as the majority religion."

For NAT, aside from being a majority, Islam must get a place in politics and the economy because it has contributed to the struggle for independence. In addition to having played a significant role in driving out invaders, Islam also had experienced glory during the kingdom of Indonesia. Because of that, the 212 Islamic Group wanted the rise of Islam. The obsession with the rise of Islam has also been the desire of the previous Islamism movement throughout Indonesia, but the obsession has failed.

An activist at the Muslim Journalists Forum, GUN, stated:

"Obsession of the rise of Islam was one of the essential factors for the group to make an active and total movement in the presidential election. With Amar Maruf and Nahi Mungkar, besides working hard, the figure chosen must be able to compensate or defeat the incumbent to gain victory in the presidential election."

Amar Maruf and Nahi Mungkar are obligated to carry out to do good and prevent actions that are not commendable, which lead to sin. HAS stated:

"Several figures became the group's choice to become presidential candidates, including Anies Bawesdan, Gatot Numantyo, Yusril Ihza Mahendra, Zulkifli Hassan, Hidayat Nur Wahid, and Prabowo Subianto."

However, Prabowo was considered the right choice to become a presidential candidate based on political and personal considerations. Prabowo was most worthy of being nominated because first, at the time, based on a survey of several institutions, the Gerindra Chairperson had the highest electability compared 
to other alternative candidates. Among other political figures, only Prabowo was believed to be able to keep up with Jokowi. Secondly, Prabowo was the General Chairperson of a political party with many seats in parliament so that it becomes easy for the former vice-presidential candidate in 2019 to get a ticket for the nomination. Finally, Prabowo only needed additional support from one political party, such as PAN, PKS, or the Democratic Party to be a presidential candidate. In the 2019 presidential election, to compete as a presidential candidate, one must get support from the political party or a joint that gets a $20 \%$ seat or a $25 \%$ vote in the 2014 election (Parliamentary Threshold).

In addition to political considerations, support for the former commander of the Army Strategic Command was due to personal considerations, including, first, Prabowo was considered to have the firmness and courage to safeguard the sovereignty of this nation. Second, Prabowo is considered to have qualified intelligence and formal education abroad, so he was believed to bring Indonesia to be respected internationally. Islamic leaders and supporters of Prabowo also gave the same assessment in the 2014 presidential election (Aspinall 2015). Third, Prabowo was considered close to Islamism. KHA stated:

\begin{abstract}
"Prabowo's proximity to Islamism was a long-standing one. This closeness has been established since Prabowo became the Special Forces Commander in the New Order Era. Prabowo's concern for the ulama cannot be doubted because he is so close to the ulama. His good relationship with Islam did not only occur during this presidential election but began long ago since he was still serving as a soldier. Moreover, he has is close to Kyai Abdul Rasyid, the head of the As Syafiiyah college, a senior cleric we respect. Through Kyai Abdul Rasyid, we can more easily communicate with Prabowo."
\end{abstract}

Relations are getting closer because, in the 2014 presidential election, most of the figures from the Islamism group supported Prabowo and Hatta Rajasa as presidential candidates and vice-presidential representatives (Mietzner \& Muhtadi 2018). Furthermore, harmonization between the Islamism Group (the 212 Islamic Group) and Prabowo was maintained because the two sides worked together to defeat Ahok in the 2017 Jakarta Governor Election. After the pair Anies Baswedan and Sandiaga Uno were declared leaders by several survey agencies, Prabowo made a speech at the Istiqlal Mosque to praise the 212 Islamic Group as an important actor to defeat Ahok.

With the support of clerics, qualified candidates, and the existence of narratives about the leadership of the Jokowi's government, which is considered secular, and narratives about the rise of Islam, the 212 Islamic Group actively and militantly created political activities to defeat Jokowi in the presidential election. Political militancy is not only carried out by ideologizing public spaces by forming narratives, discourse in mosques and social media, but also functional movements such as holding demonstrations so that elections are not fraudulent, forming and training witnesses on duty at polling stations, campaigning formally or informally. MAR stated that "as a consequence of supporting candidate number 02 (Prabowo Subianto-Sandiaga Uno), we carry out practical works such as escort so that the presidential election is not fraudulent. Besides, we are enthusiastic to struggle because we see that most Muslims want a change in the nation."

During the presidential election, the praxis activities are different from the traditions carried out by the ulama before when conducting political activities. In carrying out their activities, the ulama tend to only issue fatwas without being fully involved in operational work in the field. Militant praxis is carried out based on several things; the first struggle in the presidential election is the struggle for divinity to establish Amar Maruf Nahi Mungkar to create the glory of Islam. This is supported by GUN's statement:

"Choosing a leader for Muslims who believe in the Quran as their life's guideline is necessary as an effort to produce just, trustworthy, and fathonah leaders. Fighting in the presidential election is not just a matter of religion. It is also a matter of religion because the leader's role is crucial to determine the nation's future, including for the benefit of Islam. The presidential election is to run the ma'ruf nahi mungkar. 
Secondly, there are fears and assumptions that the 2019 presidential election was carried out fraudulently. The 212 Islamic Group alleges that fraud has taken place systematically and massively in the presidential election. In this case, MAR stated that "the violations that occurred in the massive event could not only be done by the election organizers. They believe that the government must also be responsible for fraud."

They deeply regretted when the government silenced allegations of fraud that occurred in the presidential election. Second, three crucial figures in the government, namely Wiranto, Luhut Binsar Panjaitan, and Moeldoko, should solve the problems on the Permanent Voter Registered (DPT) because these three have secured access to the election organizer. Third, the 212 Islamic Group saw that political contestation in 2019 is fighting for the number one person in Indonesia and betting the future of Islam. Deputy Chairperson of the Istiqal Ulama Fatwa Ulama Guard Movement's, RAS, stated, "Defeat at the presidential election will make the future of Islam bleak."

The activities and narratives raised by the 212 Islamic Group have made political competition between the Prabowo Subianto-Sandiaga Uno and Jokowi-Ma'ruf Amin occur tightly. The activities, discourse, and narration formed by the group that made Rizieq Shihab a role model had divided the community to be the pros and cons of Jokowi. 212 Islamic Group always disseminated discourse that the Jokowi's camp was a party that did not obey the teachings of Islam and was not supported by scholars. Following Foucault's thought, the discourse has constructed reality; therefore, the discourse is considered a truth, even though it is not necessarily an objective reality (Ahonen et al. 2014). In this context, the discourse showing that Jokowi's supporters were not devout Muslims was not necessarily honest because many supporting figures came from Nadlatul Ulama. Jokowi's supporters were scholars who had religious observance and were obeyed by many people (santri).

The 212 Islamic Group made the 2019 presidential election dynamic (fierce competition), hot, and boisterous. Not a few political upheavals were raised by both parties by bringing up dissertations with hate speech and false information (hoaxes). "Public uproar" can occur because of the formation and battle of opinions raised by both parties on social media and online media. Both parties, especially the 212 Islamic Group, utilized social media to gain sympathy, form influence, and mobilize public support (Ahyar 2019). Social media has benefited the 212 Islamic Group because with a more limited political network throughout Indonesia, they can affect many remote people's awareness to follow the discourse or narration that was formed. With social media, the 212 Islamic Group could interact and communicate with the community without being prevented or controlled by the government. Social media or online media can be an effective means of spreading ideas, influences, or resistance because the messages conveyed can spread quickly (simultaneously) and reach all places and all walks of life (Castells 2010).

Social media will always be associated with youth because this age group is the most active producer and user consuming news. Therefore, the 212 Islamic Group can utilize social media because sympathizers and members of the group come from exact departments in well-known campuses in Indonesia (Mubarak 2007; Hasan 2009; Woodward et al. 2013). The students from Jamah Tarbiyah (Prosperous Justice Party) and Hizbut-Tahrir Indonesia (HTI) are educated groups who have high skills in using telecommunications technology (social media and online media) (Nisa 2018, Slama 2018). These groups have become an active part of spreading ideas of Islamism in the reform era (Hamayotsu 2011). A Muslim scholar from the Moderate Islamic Group, ABD, said:

\footnotetext{
"Having this group made the camp win the battle in cyberspace and the digital sphere. Therefore, it is natural that the group is more able to master social and online media during the 2019 presidential election because young people in the 212 Islamic Group are technology literate. They make telecommunications technology a part of them."
}

The telecommunications expert from 212 Islamic Group, HER, said:

"Because technology has become a part of life, young people who are sympathizers of this group have many ways to gain influence in the digital world and avoid pressure from the country in cyberspace. 
We have groups in WA for each province. WA has a safer channel than the others. Often when the mujahadah encounters problems, it moves to WA. In the struggle in the presidential election, social media's function is used to expand support to the community and establish confidence for the community internally. In this case, social media will strengthen the existence of the echo chamber community, a community whose views are homogeneous and do not have alternative views in seeing a problem."

According to NIA, chief editor of Nu Online, when PBNUs official website involves public emotions, certain parties can use virtual media to make narratives perceived to be untrue; for example, it can be seen by the presence of Muslim Cyber Army activists dealing with law enforcement agencies. In addition to members and sympathizers who are technologically savvy and penetrative on social media, another factor that makes the 212 Islamic Group relatively dominate public space in cyberspace in the 2019 presidential election is that quantitatively, the number of online media affiliated with these groups is bigger compared to other groups. Based on findings from the Cyber NU and LTNU teams, more than 200 websites affiliated and sympathized with the group (Suaraislam.com 2017). Furthermore, based on the monitoring of Dutaislam.com (2018), the twelve largest and most popular Islamic da'wah sites on the first page of Google are sites affiliated with the group. Among these sites, ten of them are Salafi Islamic media. Four out of ten sites were blocked by Kominfo in 2017 for carrying out SARA propaganda, insulting government symbols, and spreading hate speech in the name of religion.

Events also influence the determination to master and win the battle in the digital space in the Islamic world. The group has learned from the Arab Spring movement experience, a popular movement that can undermine the authorities (Dunne 2015). The Arab Spring incident is a popular resistance movement initiated by young people using information technology to bring down rulers (Athamneh \& Sayej 2013). This event is also a sign that the 21 st century is the era of information technology as an essential medium for human life (Herdiansah \& Sumadinata 2019). Without meeting other people in person, through information technology in the 21st century or what is known as the internet age, political subjects can create meaning and exercise political control (Lynch 2015; Lim 2017).

In the 2019 presidential election, the ability to ideologize mosques was an essential factor in the success of the 212 Islamic Group in making the election balanced. In addition to ideologizing public space, the group also placed the mosque as a basis for their identity politics. As happened in Jakarta, the group relatively controlled large mosques in the city center to carry out religious indoctrination in the interests of the presidential election, as was done at the Sunda Kelapa Mosque, Al Azhar. The mosque became a place to emerge the fidelity of Islamic leaders known as the Istiqlal Shield. According to RA, an agreement was made at the Istiqlal Mosque to require Muslims to choose an Islamic leader. As a group of Islamism, what the 212 Islamic Group does in using the mosque as a basis for struggle, is not unique because other Islamism movements also do it. The Muslim Brotherhood spearheaded the mosque strategy as a struggle for Islamism in Egypt led by Hasal Al Bana (Roald 2010).

Active involvement in winning Prabowo in the presidential election and strengthening Islamism must also be interpreted as a change in the struggle strategy undertaken by 212 Islamic Group from the street movement to become institutionally oriented. Before the 2019 presidential election, the group was known as those who used identity politics through street movements. Besides, before the Defending Islam Action or the 212 action, the leading organizations that were part of the group, such as the Islamic Defenders Front (FPI), Hizbut Tahrir Indonesia (HTI), and the Islamic Community Forum (FUI), were also Islamism groups who always fought for their interests through street politics. Before formally supporting the Prabowo-Subianto-Sandiaga Uno pair, the group was known as those who actively used the street movement to achieve political and religious goals. When they support Prabowo and fight totally in the presidential election, it is synonymous with a change in strategy from the street movement to the institutional orientation.

Referring to what was said by Hagopian (2016), they realized that efforts to resist the government did not have to be done on an informal path (street) but could be done through an institutional route. As 
Diamond (2015) said, the change in approach shows that the awareness of the group to gain political influence requires a struggle in the existing political system.

What is unique about the groups' political behavior is that, although they have realized the importance of formal institutions to achieve their goals, they have not abandoned the street movement to win the 2019 presidential election. In this case, political behavior is political participation to elect and provide support in the election/presidential election (Huntington \& Nelson 1977) and do demonstrations and boycotts (Smith 2014). In this context, the groups' political behavior must be interpreted as a group political struggle through political institutions or by undergoing a political process (including demonstrations) (Surbakti 1992).

The belief or view of the 212 Islamic Group that the formal institutionalization (structural power) is essential to realize the interests because it saw what had happened at the Indonesian Muslim Intellectuals Association (ICMI) at the end of the New Order regime led by Suharto (Ret.). Proximity to Suharto made the organization led by B.J Habibie at that time be able to place his cadres as ministers and other vital positions in government (Pepinsky 2014). Because it succeeded in placing cadres in government and political positions, the organization of Islamism succeeded in carrying out the Islamization in the government, such as making many government officials obedient to worship and making community life more religiously nuanced by building more mosques and developing more religious community behavior. However, along with its success in Islamizing the government and society, ICMI seems to have silenced the mistakes made by Suharto, primarily related to the practices of Corruption, Collusion, and Nepotism (KKN) (Hefner 2001).

\section{Conclusion}

The power relations between Islam and the government in history in Indonesia are volatile. At certain times, there are Islamic groups that build harmonious relations with the government. However, in another era, Islamic groups (parts of Islam) conflicted with the government. The conflicts between Islamic groups and the government always occur in authoritarian regimes. Unlike previous experience, the conflict between the Islamism group represented by the 212 Islamic Group against the government occurred in a democratic era. In the democratic government led by Jokowi, the 212 Islamic Group actively fought against Jokowi's government. Resistance by the group began withholding the Defending Islam Action or the 212 action in 2016. Although the action aimed to prosecute Basuki Tjahaja Purnama (Ahok), the Governor of DKI Jakarta, to be imprisoned for alleged blasphemy, the demonstration was basically as resistance to Jokowi, who was considered a secular leader.

Resistance against Jokowi continued in the 2019 presidential election by supporting Prabowo-Sandiaga Uno's pair against Jokowi-Ma'ruf Amin. Using Islamic identity and symbols, the 212 Islamic Group fought against Jokowi as the incumbent in the 2019 presidential election, heroically and militantly. Resistance was carried out in various ways, such as demonstrations, forming and training witnesses in charge of polling stations (TPS), consolidating movements to the regions, or carrying out mosques and social media ideologies, which had made the presidential election contestation dynamic and tight. The dynamic and rigorous presidential election divided society into two camps: pro and cons to Jokowi or those considered to be religiously obedient and those considered ignorant of Islamic teachings.

The support given to the Prabowo Subianto-Sandiaga Uno pair shows that the 212 Islamic Group has changed its perspective; if previously, the group believed that the road movement was the right way to realize its interests, it then turned into a politically-oriented organization. They believe that formal institutions (power structures) are essential to obtain to develop Islamism. The group learned from the experience of the Indonesian Muslim Cendekiawan Association (ICMI), who succeeded in Islamizing the government and community through governmental positions at the end of the government led by the General (Retired Suharto). While the Islamism Group had experienced a glorious period at the end of Suharto's reign, during the Jokowi's reign, the 212 Islamic Group saw that Islam was on the periphery. 
Because of these conditions, the group saw that Jokowi was detrimental to Islam. The accusation that Jokowi has harmed Islam and is considered a secular leader is the cause of the 212 Islamic Group opposition to the government.

This study also found three aspects that contributed to strengthening the 212 Islamic Group movement, including first, the discourse stating that the government led by Joko Widodo was secular. The discourse persuaded many Muslims to stigmatize the government as hostile to Islam and made many people actively voice for the change of national leadership (Jokowi) in 2019. Second, the group's ability to ideological public spaces (mosques and social media). The 212 Islamic Group succeeded in spreading and penetrating ideas to other parties and strengthening internal solidarity because many of its members and sympathizers are skilled in using social and online media for political purposes. In addition, the use of mosques in big cities for its struggle makes the 212 Islamic Group able to generate ideas, consolidate movements, and form influence in the presidential election.

\section{References}

Ahonen P, Tienari J, Meriläinen S, \& Pullen A (2014) Hidden contexts and invisible power relation: A Foucauldian reading of diversity research. Human Relation Journal 67 (3):263-286. https://doi. org/10.1177/0018726713491772.

Ahyar M (2019) Aksi bela Islam: Islamic clicktivism and the new authority of religious propaganda in millennial age in Indonesia. Indonesian Journal of Islam and Muslim Societies 9 (1):1-29. https:// doi.org/10.18326/ijims.v9i1.1-29.

Aspinal E (2015) Oligarchic populism: Prabowo Subainto's challenge to Indonesian democracy. Southeast Asia Journal 99:1-28. https://doi.org/10.1353/ind.2015.0002.

Athamneh W \& Sayej CM (2013) Engaging the authoritarian state: Voices of protest in Syria. Journal of Arabic and Islamic Studies 13:169-190. https://doi.org/10.5617/jais.4632.

Barton G (2010) Indonesia: Legitimacy, secular democracy in Indonesia. Politics \& Policy Journal 6 (1):1-23. https://doi.org/10.1111/j.1747-1346.2010.00244.x.

Bruneissen M V (2002) Genealogies of Islamic radicalism in post-Suharto Indonesia. South East Asia Research Journal 10 (2):117-14. https://www.jstor.org/stable/43818511.

Castells M (2010) The Power of Identity. West Sussex: Willey Blackwell.

Diamond L (2015) Facing up the the democracy repression. Journal of Democracy 26 (1):141-155.

Dutaislam.com (2018) "Media Islam Jihad" dikuasai situs Islam terbesar dan terpopuler di Google. Duta Islam, 10 Maret. [Accessed 29 March 2020]. https://www.dutaislam.com/2018/03/media-islamjihad-dikuasai-situs-islam-terbesar-dan-terpopuler-di-google.html.

Dunne M (2015) After the Arab spring caught in historys crosswinds. Journal Of Democracy 26 (4):7579. https://doi.org/10.1353/jod.2015.0063.

Fealy G (2016) Bigger than Ahok: Explaining the 2 December mass really. Indonesia at Melbourne. [Accessed 29 March 2020]. http://indonesiaatmelbourne.unimelb.edu.au/bigger-than-ahokexplianing-jakarta-2.

Fealy G D \& Bush R (2014) The political decline of traditional ulama in Indonesia: The state, Umma and Nahdlatul Ulama. Asian Journal of Social Science 42 (5):536-560. http://www.jstor.org/ stable/43495819.

Hagopian F (2016) Brazil's accountability paradox. Journal of Democracy 27 (3):119-128.

Hamayotsu K (2011) The end of political Islam? A comparative analysis of religious parties in the Muslim democracy of Indonesia. Journal of Current Southeast Asian Affairs 30 (3):133-159. https://doi.org/10.1177/186810341103000305.

Hasan N (2009) The making of public Islam: Piety, agency and commodification on the landscape of the Indonesian public sphere. Contemporary Islam 3:229-250.

Hadiz VR (2018) The floating Ummah in fall of Ahok in Indonesia. TRaNS: Trans-Regional and -National Studies of Southeast Asia 7 (2):271-290. https://doi.org/10.1017/trn.2018.16.

Hefner (1993) Islam, government, and civil society: ICMI and the struggle for the Indonesian middle class. Indonesia 56:1-35. https:/www.jstor./stable/3351197. 
Hefner RW (2001) Muslim and Democration in Indonesia, Civil Islam. Princeton:Princeton University Press.

Herdiansah AG \& Sumadinata WS (2019) Indonesia political culture in the new digital age: A preliminary discussion. Masyarakat, Kebudayaan dan Politik 31 (4):378-389. http://dx.doi.org/10.20473/mkp. V32I42019.378-389.

Heiduk F (2012) Between a rock and a hard place: Radical Islam in post-Suharto Indonesia. International Journal of Conflict and Violence 6 (1):27-40. https://doi.org/10.4119/ijcv-2928.

Huda MS (2019) The local construction of religious blasphemy in East Java. Journal of Indonesian Islam 13 (1):96-114. https://doi.org/10.15642/JIIS.2019.13.1.96-114.

Huntington SP \& Nelson J (1977) No Easy Choice: Political Participation in Developing Countries. Cambridge: Harvard University Press.

Lim M (2017) Freedom to hate: Social media, algorithmic enclaves, and the rise of tribal nationalism in Indonesia. Critical Asian Studies 49 (3):411-427. https://doi.org/10.1080/14672715.2017.134 1188.

Lynch M (2015) After the Arab spring: How the media trashed the transitions. Journal of Democracy 26 (4):90-99.

Mietzner M (2018) Fighting iliberalism with iliberalism: Islamist populism and democratic deconsolidation in Indonesia. Pacific Affairs 91 (2):261-282. https://doi.org/10.5509/2018912261.

Mietzner M \& Muhtadi (2018) Explaining the 2016 Islamist mobilisation in Indonesia: Religious intolerance, militant groups and the politics of accommodation. Asian Studies Review 42 (3):119. https://doi.org/10.1080/1037823.2018.1473335.

Miichi K (2019) Urban sufi and politics in contemporary Indonesia: The role of dhikr association in the anti-'Ahok' rallies. South East Asia Research 27 (3):225-237. https://doi.org/10.1080/09678 28X.2019.1667110.

Mubarak MZ (2007) Geneologi Islam Radikal di Indonesia: Gerakan Pemikiran dan Prospek Demokrasi. Jakarta: LP3ES.

Natsir B (2017) Tabbir Rabbani Rekayasa Allah di Balik Aksi 212. Jakarta: AQL Pustaka.

Nisa EF (2018) Social media and the birth of an Islamic Social Movement: ODOJ (One Day One Juz) in contemporary Indonesia. Indonesia and the Malay World Journal 46 (134):24-43. https://doi.or $\mathrm{g} / 10.1080 / 13639811.2017 .1416758$.

Pepinsky TB (2014) Political Islam and the limits of the Indonesian model. Taiwan Journal of Democracy 10 (1):105-121.

Prasetyo J (2019) Lima tahun ke depan Indonesia makin suram. Al-Wa'ie, 28 December. [Accessed 20 June 2021]. https://al-waie.id/fokus/lima-tahun-kedepan-indonesia-makin-suram/.

Roald AS (2010) From theocracy to democracy towards secularisation and individualisation in the policy of the muslim brotherhood in Jordan. Journal of Arabic and Islamic Studies 8 (7):85-107.

Slama M (2018) Practising Islam through social media in Indonesia. Indonesia and the Malay World Journal 46 (134):1-4. https://doi.org/10.1080/13639811.2018.1416798.

Smith IO (2014) Election boycotts and hybrid regime survival. Comparative Political Studies 47 (5):74376. https://doi.org/10.1177/0010414013488548.

Suaraislam.com (2017) Tim cyber NU: Ini daftar website kelompok-kelompok radikal. Suara islam, 30 May. [Accessed 29 March 2020]. https://www.suaraislam.co/tim-cyber-nu-ini-daftar-websitekelompok-kelompok-radikal/.

Surbakti R (1992) Memahami Ilmu Politik. Jakarta: Gramedia Widiasarana.

Van Dijk K \& Kaptein NJ (2016) Islam, Politics and Change: The Indonesian Experience after the Fall of Suharto. Rapenburg: Leiden University Press.

Woodward M, Amin A, Rohmaniyah I, \& Lundry C (2013) Getting culture: A new path for Indonesia's Islamist Justice and prosperity party? Contemporary Islam 7 (2):173-189. https://doi.org/10.1007/ s11562-012-0187-x. 